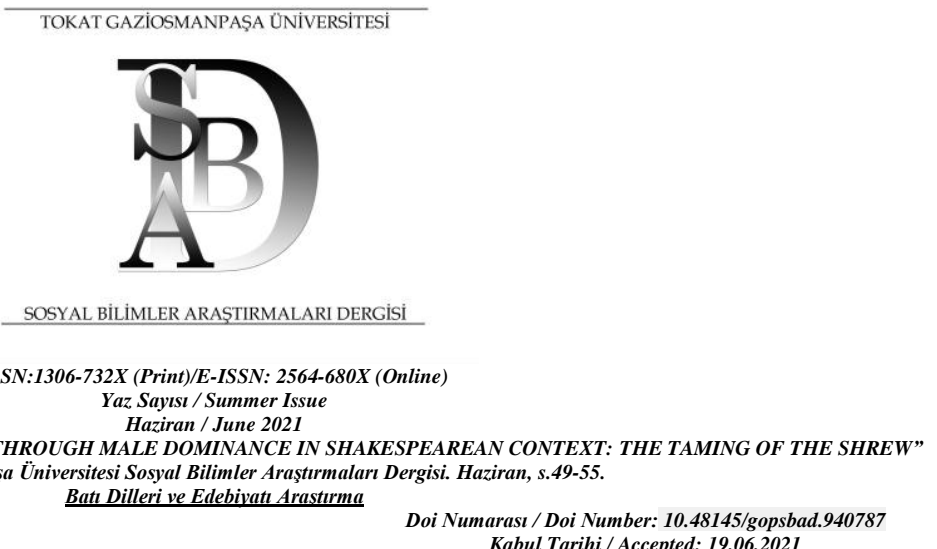

Geliş Tarihi / Received: 21.05.2021

Kabul Tarihi / Accepted: 19.06.2021

\title{
CINDERELLA COMPLEX CREATED THROUGH MALE DOMINANCE IN SHAKESPEAREAN CONTEXT: THE TAMING OF THE SHREW
}

\author{
Cüneyt ÖZATA ${ }^{1 *}$ \\ ${ }^{l}$ Ordu Üniversitesi, Ingiliz Dili ve Edebiyat,, Ordu, Türkiye $/{ }^{I}$ Ordu University, English Language and Literature, Ordu, Turkey \\ cuneyt.ozata@hotmail.com \\ ${ }^{+}$ORCID: 0000-0002-9179-9537
}

\begin{abstract}
Making a great many contributions to theatre itself, William Shakespeare has widely been acknowledged as the father of English language and literature as well as the greatest playwright in English history. Apart from his poems and sonnets, he produced several influential and well-known plays standing for the customs and lifestyle of Elizabethan age. His basic motif to create such works seems to shed light on the era, probably to criticize the issues which he postulated as flaws of the society. Even in his comedies, Shakespeare blended comic elements with critical messages as in The Taming of the Shrew (1623) ranking among the most debatable comedies while inholding some serious subject matters related to male hegemony in his age. In this present study, this play is analysed through the concept 'Cinderella Complex' explicated by Colette Dowling. Specifically, the shocking transformation of the 'shrewish' Katherina is detailed with regard to this concept. The findings are presented in the conclusion section of the study. Keywords - Cinderella Complex, Shrew, Male Hegemony, Submission, Obedience.
\end{abstract}

\section{SHAKESPEARE BAĞLAMINDA ERKEK EGEMENLIĞİiNIN YARATTIĞI SINDDELLA KOMPLEKSİ: HIRÇIN KIZ}

Öz-Tiyatro sanatına yaptığı birçok katkı göz önüne alındığında, William Shakespeare büyük ölçüde Ingiliz dili ve edebiyatının babası ve İngiliz tarihindeki en büyük oyun yazarı olarak dünya çapında kabul görmektedir. Shakespeare, şiirleri ve sonelerinin yanı sıra Elizabeth döneminin yaşam tarzını ve gelenek/göreneklerini temsil eden çeşitli etkileyici ve dünyaca tanınmış oyunlar kaleme almıştır. Yazarın bu tür eserleri ortaya koymasındaki temel amaç çağa ışık tutmak belki de toplumun kusurları olarak kabul ettiği konuları eleștirmektir. Komedilerinde bile Shakespeare, erkek egemenliğiyle ilgili ciddi açmazları içerisinde barındıran unsurları ön plana çıkararak, en tartışmalı komedileri arasında yer alan Hırçın Kız (1623)'da olduğu gibi, ciddi mesajları komik unsurlarla harmanlamaya özen göstermiştir. Bu çalışmada, Shakespeare'in Hırçın Kız adlı oyunu, Colette Dowling'in açıklığa kavuşturduğu 'Sindrella Kompleksi' kavramı üzerinden incelenmektedir. Özellikle, oyunun 'hırçın' karakteri Katherina'nın değişimi 'Sindrella Kompleksi' kavramına göre detaylandırılmaya çalışılmıştır. Çalışmanın bulguları sonuç kısmında verilmektedir. Anahtar Kelimeler-Sindrella Kompleksi, Hırçın, Erkek Egemenliği, Teslimiyet, İtaatkarlı. 


\section{INTRODUCTION}

Looking at Shakespeare's past, it is seen that he was the son of a family that was known and had influence in the society. It is known that his father John Shakespeare was a successful businessman among many tradesmen, and his wife Mary Arden was the heir of Robert Arden, one of the leading landowners. In an age where status in society was of great importance, John Shakespeare applied for a family coat of arms to raise the social status of his family, but his request was denied. Stepping into the theatre at an early age, William helped his family gain status by earning plenty of money by buying shares in the theatres he performed. Shakespeare's purchase of the New Place in Stafford with the income he earned from the theatre enabled the family to gain a high position and this position paved the way for the family coat of arms. With the coat of arms, the family got out of the working class and gained a higher status. The coat of arms consists of a hawk figure holding a silver-tipped spear, and under the coat of arms there is a slogan that appears in most of Shakespeare's later documents: "Non sans droict", meaning "Not without right".

In the 21st century, Shakespeare is the first author that a reader will encounter on the shelves when $s / h e$ enters a bookstore to satisfy her/his intellectual hunger. He is the first author to be mentioned in literary or theatre conversations where modest groups come together. There is only one reason for Shakespeare's inexhaustible popularity: that he is a writer for all ages and that this popularity is not without right, as seen in his coat of arms. The main reason why Shakespeare's works have been translated into almost every language spoken in the world despite dozens of talented writers such as his contemporaries Robert Greene, Thomas Lodge, George Peele, Thomas Nashe, and that everyone has read at least one of his works is the availability of analysis opportunities even centuries later through the works of many concepts that did not exist at the time. Many writers, from Freud to Lacan, from Barthes to Foucault, have something to say about Shakespeare. Reading Coriolanus (1623) through Marxism, Othello (1603) through racism, Twelfth Night (1623) homosexuality, As You Like It (1599) gender, and Hamlet (1603) through a psychoanalytic view is the obvious example. Colson, O'Hara and Jason touch upon the versatility and sophisticated nature of Shakespeare in a similar way:

To speak of Shakespeare as the world's greatest dramatist is inadequate. It would be closer to the mark to speak of him as a philosopher, a psychologist, or a poet possessed of the artistry that enables him to express his perceptions in dramatic form, and in so doing render them with unique subtlety and communicative power. (2015: 19)

Shakespeare, who ignored the insufficient stage instruments of the period and was a word master, tried to convey his main message to his audience through the language he used since the inadequacy of props in his age necessitated more attention given to language (Foley \& Coates, 2018: 64). Shakespeare's emphasis on language forced the ideas contained in his works to come to light. Since Shakespeare, who made an incredible contribution to the English language, sheds light on every age from past to present, it is an undeniable fact that his works are universal. As regards to his literature, Ackroyd expresses:

He reclaimed the English language at the same time as he restored the essential themes of English literature from the days of the Anglo-Saxons. He wrote of dreams and visions; he invoked ghosts and witches; he was in love with English history, he revived the spectacle and pageantry of the medieval religious plays. (2010:11)

The Taming of The Shrew (1623), one of the author's early plays, is a literary work open to reading within the framework of gender equality and the status of women in the society of that period, which is one of the important topics of discussion today. This farce-type play, inspired by Plautus's Latin comedies, is known as a comedy of intrigue. The play begins with an induction on a drunk man named Christopher Sly, who can be considered a street vagrant, by the men under the king's command to both make the king laugh and have fun. In this pre-play, Christopher Sly is treated as if he fell ill for a while and lost his memory. Sly believes in this deception so much that he thanks God for his recovery. Wandering in a fantasy world, Sly is told by a servant that it would be good for him to watch a play, an advice of the doctors. The Taming of The Shrew is a play in the form of a playwithin-a-play, which is one of the elements predominantly seen in Shakespearean comedies, in which this man, who is in fact a street bum but also falls prey to the deception that he is a king, watches unawares the con played on him like a king. The audience accustomed to the nature of Shakespearean plays meets with "not a 'realistic' play but a male fantasy" (Ackroyd, 2010: 90).

\section{DISCUSSION}

In Elizabethan age, the role of women, either domestic or public, was imposed on them by the patriarchal system governed by male mentality which regarded women as "inherently inferior, uncontrollable, and prone to a wide range of vices and disabilities" (Kemp, 2010: 31). In parallel, most of the female characters are indeed portrayed as meek and victims like Cordelia and Ophelia from the very beginning of the plays till the end in Shakespearean world whereas the other ones are demonic and ill-hearted like Lady Macbeth. The audience encounters "logocentric fascination with Shakespeare's words as the bearers of authorial meanings" (Rutter, 2001: xiv). However, Shakespeare stepped out of his line by means of the character Katherina seeming unexpectedly strong and rebellious at first even if she transforms into another familiar female figure of him at the end of the play. The word 'tame' in the title of the play usually means taming wild animals, according to Oxford dictionary. In this sense, it is possible to observe that women were seen as wild and combative animals that had to be tamed. Regarding the Elizabethan period, women's rights in England, which was ruled by a woman who can be called the god of the earth, are the opposite of this 
situation. Apart from the nobles, women were not given the right to education, and noble women who were educated were subjected to this education so that they could behave in a mannerly fashion beside their husbands. In a sense, "the household was the microcosm of the State, and women's subjection a happy paradigm of civil order" (Dusinberre, 1996: 79). The main duty of the woman was to serve her husband, and her failure to meet his desires or to obey his orders was enough to put the label of shrew. In other words, the education of women is only through taming. In a similar vein, it might be necessary to state upon the 'taming' of Katherina:

In the 16 th century a woman had to do little more than challenge a man's opinion to be termed a "shrew." She might be labeled "shrewish" if she spoke too much, or appeared mean spirited or sexually promiscuous. There were many ballads and folk tales about unruly wives that Shakespeare could have based his presentation of Katherine around. Here is a verse of a ballad called The Cruel Shrew: "She never lins her brawling, / Her tongue it is so loud; / But always she'll be railing, / And will not be controlled. / For she the breeches still will wear, / Although it breeds my strife. / If I were now a bachelor, / I'd never have a wife. (Colson, O'Hara \& John, 2015: $35)$.

Katherina, who appears in front of the audience with a wild and unhappy image at the beginning of the play, spits venom towards everyone. This character, who lives under the sovereignty of his father in the absence of a mother figure, or rather under his yoke, is the symbol of an uprising against the male-dominated society. Another female character that is important in the play and deliberately presented to the audience in the form of Katherina's contrast is her sister Bianca. Bianca, who has a more naive and obedient character compared to her sister, is a woman that meets the expectations of the society. The contrast between these two women is a society-determined and unchangeable reality. As Gündüz points out, "the dominant male gaze establishes this opposition of the two sisters by comparing them and defining them with labels: obedient, quiet, submissive or harsh, shrewish" (2018: 838). The aim of their father, Baptista, who is expected to find balance between his daughters but fails to do so, is to find a husband and get rid of Katherina, who is stubborn and sharp-tongued, and then to find a partner to her other daughter Bianca, who looks like a good-natured and soft-spoken woman. Expressions such as "the fiend of hell" told to Katherina in this process of finding a spouse further stimulate her shrewish nature (Shakespeare, 1998: 1046). Katherina, who appears as a rebellious woman at her father's house and outside and draws the profile of a woman who will not slant towards anyone, is a character who is satisfied with her situation and does not need a "saviour" like a husband on whom she will always feel dependent. Baptista says that he will allow her younger daughter's marriage only on the condition that her eldest daughter
Katherina marries first. Baptista expresses how serious he is in this decision in his words, "that is, not to bestow my youngest daughter before I have a husband for the elder" (Shakespeare, 1998: 1046). While the characters of Hortensio, Gremio and Cambio, who are the suitors of Bianca, resort to various tricks to win the love of the woman they love, Petruchio, a nobleman from Verona, does not mind Katherina being called a shrew, and is eager to marry her and to 'tame' her, with a plan to get the young woman's considerable dowry in the process. In the dialogue between Baptista, Gremio and Katherina in Act I, after Baptista reveals the requirement of her daughters to marry, Katherina reveals her anger as she expresses her discomfort at being "a stale of me amongst these mates" (Shakespeare, 1998: 1046):

I'faith, sir, you shall never need to fear.

Iwis it is not half to her heart.

But if it were, doubt not her care should be

To comb your noddle with a three-legg'd stool,

And paint your face, and use you like a fool. (Shakespeare, 1998: 1046)

Starting with the first act, Katherina clearly shows that she is not a docile but an unyielding woman, contrary to the female understanding of the period. Her sister Bianca, however, uses her beauty and innocent stance as a shield and plays a complete innocent role by taking shelter behind her profile. Shakespeare, who put Bianca as a contrast to Katherina, tries to show the audience what the desired type of woman was like in the society of that period. Constant comparison of Katherina to her younger sister from an early age and the father's interest in Bianca, who was sympathetic and more docile, made Katherina even more aggressive. Her need for love and attention and her resentment of her father become even more evident in these words: "You have show'd a tender fatherly regard" (Shakespeare, 1998: 1054). As a result, Katherina appears to the audience as a character who has developed the instinct of staying alone and protecting herself against men. What Katherina did not anticipate or foresee is the sudden disappearance of her harsh attitude towards men.

Women raised in the patriarchal system are married by their fathers, who are in the position of supplier and guardian of the house, with the belief that they will be protected with a happy marriage and that they will find a good partner, without their consent. Other works describing women like this work have also taken this situation as a basis. They are "not merely records of female subjugation, but ideological methods of endorsing and indoctrinating the misogynist ideas underpinning patriarchal society" (Wootton \& Holderness, 2010: 2). Within the framework of the patriarchal society they live in, the only branch in which they can hold on to life is either their father or their spouse, and it has been imposed on women from their childhood. While many women are 
brought up in a family environment in accordance with the norms set from their childhood, they are told stories that depend on miracles in real life in their childhood stages. One of these tales is the Cinderella tale. Cinderella, a poor young girl, is a character who acts as a maid at home with her stepmother and two sisters at the beginning of the story but reaches real happiness by marrying a prince miraculously at the end of the tale, who she cannot even imagine. Cinderella Complex, which was rooted from this tale and first coined by Agatha Christie, was later detailed in the book The Cinderella Complex: Women's Hidden Fear of Independence (1991) by Colette Dowling. Dowling explicates this psychological concept in such a way:

...personal, psychological dependency - the deep wish to be taken care of by others-is the chiefforce holding women down today. I call this "The Cinderella Complex"—a network of largely repressed attitudes and fears that keeps women in a kind of half-light, retreating from the full use of their minds and creativity. Like Cinderella, women today are still waiting for something external to transform their lives. (1991: 21)

Women who are raised under the pressure of male domination are individuals who cannot develop an idea for liberation, cannot be fully independent, feel the need to lean on a man under any circumstances, and have developed a Cinderella complex in their inner world. Therefore, "it might not be misleading to propose the idea that fairy tales stand at the very center of the construction of gender roles; the creation of a robot who is defined as 'woman' by the dominant ideology" (Kumlu, 2020: 159). The woman no longer sees the image of the man as a force built upon it, but as a self-preserving force and begins to need this power involuntarily. This is exactly the role men assign to women. In the play, Petruchio is the incarnation of the patriarchal system and the value he gives to women echoes in these words:

And do you tell me of a woman's tongue,

That gives not half so great a blow to hear

As will a chestnut in a farmer's fire?

Tush, tush, fear boys with bugs! (Shakespeare, 1998: 1050)

As it can be understood from here, Petruchio is on his way to making Katherina the ideal woman with all his determination. Although he tries to approach Katherina endearedly, he applies some kind of psychological violence. The persuasive and manipulator Petruchio initiates Katherina's journey to becoming Cinderella by praising Katherina as "pleasant, gamesome, passing courteous" (Shakespeare, 1998: 1053), in contrast to her personality. The resistance of Katherina, who does not compromise her moodiness at the beginning of the play, starts to break slowly after her marriage because there is a male figure who uses her own weapon, that is, her moodiness, against her. This verbal violence is replaced by physical violence, such as starvation and sleep deprivation, as Petzold asserts: "the actual 'taming' is not primarily achieved through words. Petruchio's actions of withholding food and sleep are more dependent on physical than verbal power" (2006: 162). These actions cause an astonishing change of Katherina's dominant character by showing an internal transformation. The outcome of this conflict between them is in fact clear from the beginning of the play. Although they seem to be opposite characters of each other, these two characters draw the image of "a co-dependent person" in need of other individuals (Giddens, 1992: 89). Katherina and Petruchio are unwanted and socially excluded types, and both fulfil their assigned roles. In connection with this, the following may be suggested:

Katherina is an outsider and she meets Petruchio who is an outsider as well. Petruchio is presented as a tyrant to sustain his position in society, yet he performs his role that within the system. If Katherina continued to act in the same way, the system would crush her. (Sönmez, 2000)

Katherina yields to her traditional role as society's expectation. This is what the people of that period expected from the character Shakespeare created. Regarding this change shown by this female character, it is still a matter of debate whether it is desperation or blind attachment. However, the underlying reason for this change is probably that the lack of parental love and the fatigue that comes with it leads to a desperate need to endure someone. Dowling confirms this with the following:

Such fears trace back to profound infantile loneliness. The need for love that goes unfulfilled in childhood can lead to a passive and potentially destructive wish to give oneself up to anyone. (1991: 79)

Katherina is never an Ophelia, she is a shrewish woman who must be trained, restrained and tamed. Katherina is not only a theatrical character, but also a symbol of all women who are expected to be submissive and docile. This is the sole purpose of the patriarchal system, turning all Katherinas into Ophelia. The main duty of a woman in a male-dominated society is to be a good wife, to have children, and to fulfil her responsibilities to her husband in a good way. Women living in such a society are raised according to the rules determined by their fathers, the dominant figure of the family, without education. When they reach a suitable age for marriage, they are married to a man they see fit. The 'home environment', which they perceive as a good 'shelter' for them and a 'stronghold' against all kinds of dangers of the outside world, is not much different from the prison. Undoubtedly, the head guard of this prison is the father or husband who is the head of the family. The situation of men taking women under their protection started with the idea of the head of the family, which is seen as a necessity for women to be taken under protection even in ancient times. Coming with an act in Roman law, the patria potestas (the power of the father) gives the pater familias an agnatic authority 
over their family. While a woman was under her father's patria potesta until she got married, she continued her life under her husband's patria potesta after marriage. Women who were not under the sovereignty of any patria potesta were appointed guardians, just like children, and the woman provided legal proceedings through this guardian. This authority, which is not based on blood ties, includes killing as well as survival. Holland addresses this scary issue as follows:

The first obstacle in women's life in Rome was the possible danger of losing their lives. This danger derived its source from a law of Romulus demanding the death of baby girls. Considering this law, all the boys and the first baby girl in a family could be raised. This was a death call for the other girls who were born after the first one. (Holland, 2016: 55)

The place of women, since ancient times, has continued in the same way for a long time. It was not possible to talk about a woman like Katherina at that time. Although Shakespeare 'tames' Katherina later, she is an important female figure who initially rebelled against the patriarchal system and made her voice heard. This system does not intend to give up the domination it has established over women, but women have started to speak out. In line with the expectations of that period, Katherina, who was a tough, shrewish, and unspoken woman at the beginning of the play, now accepts the sovereignty of the man, has been tamed and appears before the audience as Cinderella, a true fairy-tale princess. In other words, "the play enacts the defeat of the threat of a woman's revolt" (Gay, 1994: 88). Katherina has long resisted psychological / physical violence, humiliation and being seen as a commodity by the men around her. However, the need to feel belonging to a place and someone, to be loved and valued has prevailed. Although Petruchio used her own weapon against her and bullied her, the fact that he did not say any hurtful and humiliating words against Katherina, unlike his father and other men around him, eventually led Katherina to the idea that this was love. Petruchio's aim is to make this excluded woman figure 'acceptable' again according to society norms, and at the same time "restructuring or revising Kate's vocality and boldness in a more acceptable fashion" (Hjelm, 2016: 66). Petruchio does not desire a passive Katherina to obey him in a compulsive way. He wishes that she herself would want to become Cinderella. Mill states that:

All the social and natural forces gathered with the purpose of preventing the revolt of women against the male power. Their masters demanded much more from them in addition to active service. All the men except for the wild ones desired a voluntary slave rather than forced one from a woman to which they were deeply attached, in other words, a favourite rather than only a slave ------ All the women are raised through the belief that their ideal personalities need to be different from the ones of men, in other words; submission and obedience rather than free will and self-control (2017: 44).

Katherina, who emerged with a radical change at the end of the play, now found her place and became a slave to male domination. Fluttering in the absence of love and trust, this character has left her shrewish nature aside and is now a woman having the Cinderella complex. "Wifely obedience as the ultimate marker of masculine (self) control" (Crocker, 2010: 61) takes the place of disobedience and rebellious nature of Katherine. Katherina, who has evolved into a symbol of complete submission and obedience, has voluntarily undergone a complete transformation with her sense of belonging and protection. He displays a blind devotion to Petruchio, his prince on a white horse. The most obvious proof of this lies in her remarkable speech at the end of the play, "thy husband is thy lord, thy life, thy keeper, / Thy head, thy sovereign; one that cares for thee" (Shakespeare, 1998: 1069)

\section{CONCLUSION}

The subject of women has been dealt with from many different angles for centuries and has been kept up to date by many writers as a source for their works. In this context, the idea of analyzing women within certain frameworks, such as the place/role of women in society and the family, which was a common understanding in the Elizabethan period, has left its place to the idea of seeing and understanding women as individuals, which includes more comprehensive expressions. In this sense, it is possible to see a female figure who is always featured in many of Shakespeare's works. In addition to the period, Shakespeare wrote plays in which women also took a large place, showing his far-sightedness. The character of Katherine, who he brings to the forefront as a protagonist among these plays, has the feature of being a prototype woman who shapes the general flow of the play called The Taming of the Shrew. This woman, who is tried to be shaped within the framework of the rules of the maledominated society, draws an image that is quite far from the period. While women in England continued their lives under patriarchal authority for ages, they also ended their struggle, also applicable to women in Elizabethan times. Unlike the understanding of the period she was in, the struggle of the character Katherina against Petruchio is also a minimalized version of the struggle between men and women that covers a whole country. As "a character full of words that no one hears" (Kemp, 2010: 78), she unearths her lasting anger against the male hegemony which renders women worthless. In a period when male dominance was felt so intensely, Shakespeare's creation of a character like Katherina stands out as a remarkable detail. Particularly, her grudge, which shifts as the focal point of her change and transformation and feeds Katherina's thoughts, almost disappears towards the end of the play. While Katherina continues her life confidently, always preserving her grudge against Petruchio, she gradually loses her resolve in the face of 
Petruchio's various psychological / physical violence and tyranny. With this change she went through and her speech to all women at the end of the play, she proves her commitment to Petruchio and ultimately her submission to male domination, with her sense of obedience and subservience. It is likely that the main reason behind this attachment is the belonging, trust and love that she has been deprived of since childhood. Childhood is a critical period in which many complexes are formed at this point. She had these feelings towards Petruchio and entered the Cinderella complex, which is a psychological stage. Cinderella Complex, as it is known, is a psychoanalytic term derived from the Cinderella fairy tale. A prince saves Cinderella, who is ostracized and despised among her relatives, from where she lives. When we associate this with the play, Katherina also admits that the creation of her gender and her ideal personality pass through the path of submission and surrender to the control of others. However, at the end of the play, she displays the behavior she did not show to her family to the man she believes saved her. And in this way, she begins to feel that she is a woman. She accepts a social female identity, the obligations brought by this identity and the consequences of these obligations by sacrificing self-control and selfmanagement desires and ended the play as a woman shaped by a male-dominated society. The fact that Katherina begins by accepting the superiority of a man who cannot be outside the family in her change and transformation causes the feeling of emotional emptiness that she tries to suppress to surface. Nevertheless, in this situation, contrary to what is expected, the fact that the man uses insulting words other than violence, is a sign that Katherina is trapped in Cinderella Complex. If evaluated from the point of view of the woman of that day, this so-called education or domestication will not end until all Katherinas in the world turn into Ophelia. 


\section{KAYNAKCA}

Ackroyd, P. (2010). A Brief Guide to William Shakespeare without the Boring Bits, Running Press.

Colson, R., O’Hara, S. \& John, D. (Eds.) (2015). The Shakespeare Book. Penguin Random House.

Crocker, H. A. (2010). Engendering shrews: medieval to early modern. Gender and Power in Shrew-Taming Narratives, 1500-1700 (Eds. Wootton, D. \& Holderness, G.). Palgrave Macmillan.

Dowling, C. (1991). The Cinderella Complex: Women's Hidden Fear of Independence. Pocket Books.

Dusinberre, J. (1996). Shakespeare and the Nature of Women. London: Macmillan Publishers Limited.

Foley, E. \& Coates, B. (2018). Yetişkinlere Shakespeare (trans. Avcı, Z.). Helikopter Yayınları.

Gay, P. (1994). As She Likes It, Shakespeare's Unruly Women. Routledge.

Giddens, A. (1992). The Transformation of Intimacy: Sexuality, Love and Eroticism in Modern Societies. Stanford University Press

Gündüz, İ. E. (2018). Gendered identities: Shakespeare's Taming of the Shrew. Gaziantep University Journal of Social Sciences, 17(3), 834-844.

Hjelm, M. L. (2016). "Tis Bargain"d, Twixt Us": the reclamation of Kate in The Taming of the Shrew. Cultural Intertexts, 66-78.

Holland, J. (2006). A Brief History of Misogyny: The World's Oldest Prejudice. London: Robinson.

Kemp, T. D. (2010). Women in the Age of Shakespeare. Greenwood Press.

Kumlu, E . (2020). Unveiling the Implicit Political Agenda: A Comparative Analysis of the Construction of Gender Roles in Grimm's Ashputtel and Giuseppe Pitré's The Magical Little Date Tree. Litera, 30 (1), 155-175. DOI: 10.26650/LITERA2020-0006

Mill, J. S. (2017). Kadınların Köleleştirilmesi (trans. Özcan, A.). Bilge Kültür Sanat.

Petzold, J. (2006). Subverting the master discourse? the power of women's words in Shakespeare's The Taming of the Shrew and Fletcher's The Woman's Prize, or The Tamer Tamed. AAA: Arbeiten aus Anglistik und Amerikanistik, 31(2), pp. 157-170.

Rutter, C. C. (2001). Enter The Body: Women and Representation on Shakespeare's Stage. Routledge.

Shakespeare, W. (1998). The Taming of The Shrew. The Arden Shakespeare Complete Works (Eds. Proudfoot, R., Thompson, A. \& Kastan, D. S.). Bloomsbury Publishing.

Sönmez, A. (2000). Tristan Brolly ile "Hırçın Kız" Üzerine Söyleşi. Retrieved from http://feminisite.net/index.php/2000/06/tristan-brolly-ile-hircin-kiz-uzerine/ on 28th December, 2020.

Wootton, D. \& Holderness, G. (Eds.) (2010). Gender and Power in Shrew-Taming Narratives, 1500-1700. Palgrave Macmillan. 